\title{
Music related upper limb pain in schoolchildren
}

\author{
HUNTER J H FRY AND GLENN L ROWLEY
}

\author{
From 16 Howard Street, Kew, Victoria 3101, Australia
}

SUMmaRY Two British secondary schools (one a specialist music school) were surveyed to assess $\vec{\circ}$ the prevalence of upper limb pain among specialist music students compared with students in $\overrightarrow{a_{0}}$ regular school setting. Female students tended to report pain more often than male students, bus for both significantly higher prevalence was found in the music school. Pain in the regular schoo was most often attributed to writing, whereas in the music school it was associated with the playing of all instruments, but most particularly with cello, clarinet, and flute. Music students reported long hours of practice, but it appeared that the intensity of practice may be moreo important as a determinant of pain than the total hours spent practising. The results of the studye0 are in substantial agreement with those previously published from Australia and North America응 On the balance of probabilities the pain is due to overuse syndrome, which is very common in musicians and well known in writers.

Overuse related to music is now well reported in a number of modern studies, ${ }^{1-4}$ including one of Australian secondary school children which compares those who play musical instruments with those who do not. ${ }^{5}$ A study of children of the same age from Texas reported similar findings. ${ }^{6}$ The purpose of our study was to examine the occurrence of music related pain in a unique school in the north of England catering for children from the ages of 8 upwards who are gifted musically, and which provides the general as well as the musical education of these students. This was compared with a 'regular' school in the same region: fee paying, traditional, with a strong music department, and a high standard of pastoral care. The aim of the study was to compare the occurrence and characteristics of upper limb pain among the musically gifted students with that which occurs among other students in the community who may or may not play musical instruments.

\section{Subjects and methods}

Questionnaires were distributed to students in the two schools, and responses were received from all 169 students at the music school and all 348 students at the regular school. The students were not physically examined by the medical author. Students' responses were coded and analysed by computer.

Accepted for publication 21 March 1989.

Correspondence to Mr Hunter J H Fry, 16 Howard Street, Kew, Victoria 3101, Australia.
Where the results involved differences between groups or relations between variables, standard te $\mathrm{As}_{\infty}^{\circ}$ of significance were used.

\section{Results}

The distributions of students' ages were very similañ in the two schools. Ages ranged from 7 to 19 in the music school (average 14.4) and from 10 to 19 in the regular school (average 14.4). Gender balance waş quite different in the two schools: fairly even $(52 \%-$ female) in the regular school, but predominantlyo female $(63 \%)$ in the music school. This needs to be kept in mind when comparisons are made betweenc the two schools.

THE MUSIC SCHOOL

All students surveyed played one or more instruß ments, with $75 \%$ playing two or more. Table 1 list? the number and percentage of pupils playing each instrument, in order of their popularity. Because most students played more than one instrument the total number is more than the number of students (169), and the percentages do not add up to $100 \%$ N Although the piano was played by many morew students than any other instrument, it was playedb more often as a second instrument (96 students) than as a first instrument (44 students). Violin, or the other hand, was the first instrument for $44 ?$ students (equal with piano), but the second instrument for only three. Eighteen students played theo cello, and it was the first instrument for all of them 
Table 1 Instruments played-music school*

\begin{tabular}{|c|c|c|}
\hline Instrument & $\begin{array}{l}\text { Number of } \\
\text { pupils }\end{array}$ & Percentage \\
\hline Piano & 142 & 84 \\
\hline Violin & 48 & 28 \\
\hline Cello & 18 & 11 \\
\hline Flute & 11 & 7 \\
\hline Clarinet & 9 & 5 \\
\hline Harpsichord & 8 & 5 \\
\hline Viola & 7 & 4 \\
\hline Trumpet & 6 & 4 \\
\hline French horn & 6 & 4 \\
\hline Trombone & 6 & 4 \\
\hline Double bass & 5 & 3 \\
\hline Oboe & 5 & 3 \\
\hline Guitar & 5 & 3 \\
\hline Percussion & 4 & 2 \\
\hline Tuba & 4 & 2 \\
\hline Harpsichord & 4 & 2 \\
\hline Recorder & 3 & 2 \\
\hline (Singing) & 3 & 2 \\
\hline Organ & 2 & 1 \\
\hline Bassoon & 2 & 1 \\
\hline (Composition) & 2 & 1 \\
\hline Saxophone & 1 & 1 \\
\hline
\end{tabular}

${ }^{*}$ Number of pupils in the music school $=169$.

No other instruments were played by substantiai numbers of students.

Students at this school practise their instruments for long hours, claiming an average $3 \cdot 3$ hours a day. When students were asked to specify their maximum practice hours a day, one third indicated that they sometimes practised for more than five hours a day, with half of those exceeding seven hours. The question at issue is whether this has adverse effects in itself.

PREVALENCE OF PAIN

Students in both schools were asked whether they had ever experienced pain in their hands and arms related to hand use. Because of the different emphasis, the question was worded differently in the two schools: (a) Music school: Have you ever had pain in your hands and arms that appeared to be related to playing your instrument? $(b)$ Regular school: Have you ever had pain in your hands and arms that appeared to be related to hand use such as writing, sport, hobbies, carrying your case?

Thus respondents in the music school were asked to report pain resulting from a narrower range of activities than those from the regular school (because of the focus of this study it was thought desirable to direct attention specifically to music related pain in the music school). Despite this there was a significantly higher prevalence of pain re- ported in the music school than in the regular school $(71 \%$ v $50 \%)$.

Both figures are sufficiently high to cause concern, and the reasons for such high prevalence of pain warrant exploration. In the music school all pain reported was associated with the playing of musical instruments; in the regular school the reported pain was associated with a range of activities. Regular school students were asked what activities produced the pain; Table 2 summarises their responses. Writing was by far the dominant source of hand and arm pain. Over one quarter of all students (and therefore more than half of those who reported pain) attributed it to writing. The various categories of sport accounted for another $10 \%$ of the total. Music related pain was quite uncommon (six students, $2 \%$ ) and contrasted dramatically with the $71 \%$ in the music school who reported music related pain. Of other activities mentioned, only pushing and lifting (10 students, $3 \%)$ and carrying weights (12 students, $3 \%$ ) accounted in any substantial way for the occurrence of pain.

Various questions were asked of both groups about the nature and duration of the pain. The median duration reported was two years in the music school and three years in the regular school. Although the range was very large (from one week to 12 years), it was clear that for many students this was a longlasting problem. Table 3 reports the reponses to a series of questions about the nature

Table 2 Activities that produce pain-regular school

\begin{tabular}{lcc}
\hline Activity & $\begin{array}{l}\text { Number of } \\
\text { pupils }\end{array}$ & Percentage \\
\hline Writing & 93 & 26 \\
Sports & 34 & 10 \\
Music & 6 & 2 \\
Lifting and other heavy physical activity & 27 & 8 \\
Unable to say & 10 & 3 \\
Other & 4 & 1 \\
Total & 173 & 50 \\
\hline
\end{tabular}

${ }^{*}$ Number of pupils in the regular school $=348$.

Table 3 Nature and seriousness of reported pain

\begin{tabular}{llll}
\hline Characteristic of pain & $\begin{array}{l}\text { Music } \\
\text { school } \\
\text { No (\%) }\end{array}$ & $\begin{array}{l}\text { Regular } \\
\text { school }\end{array}$ & $\begin{array}{l}\text { Significance } \\
\text { of difference } \\
(p \text { value })\end{array}$ \\
\hline $\begin{array}{l}\text { Pain still present? } \\
\begin{array}{l}\text { Pain even when not using } \\
\text { hands? }\end{array}\end{array}$ & $83(49)$ & $91(26)$ & $<0.0001$ \\
$\begin{array}{l}\text { Does pain interfere with } \\
\text { schoolwork? }\end{array}$ & $11(7)$ & $66(19)$ & $<0.001$ \\
\hline
\end{tabular}


and seriousness of the pain. Students in the music school were more likely to be currently experiencing pain than those in the regular school. Because pain in the regular school was so strongly associated with writing and sport it is likely that many were reporting specific occurrences of pain associated with events such as a examinations or sporting events. Students in the music school were referring to problems associated with a continuing activity that occupied a large amount of their time. Because of their commitment to music it is probably more difficult for them to avoid the situations that produce their pain. Nevertheless only 18 of them (15\% of those reporting pain) were having treatment.

\section{WHO EXPERIENCES PAIN?}

In the regular school there was a significantly higher prevalence of reported pain among girls than among boys $\left(56 \% \vee 43 \% ; \chi^{2}=6 \cdot 1, \mathrm{df}=1, \mathrm{p}<0.05\right)$. This might suggest that the higher prevalence of pain in the music school was due to its predominantly female population. The data, however, refute this. Within the music school there was a small but statistically non-significant difference between boys and girls for reported pain (girls $73 \%$, boys $68 \%$; $\left.\chi^{2}=0.02, \mathrm{df}=1\right)$. Tables 4 and 5 show that the prevalence of reported pain was significantly higher in the music school than in the regular school, regardless of gender.

Table 4 Prevalence of pain in music and regular schools-boys

\begin{tabular}{llll}
\hline & $\begin{array}{l}\text { Music } \\
\text { school } \\
\text { No (\%) }\end{array}$ & $\begin{array}{l}\text { Regular } \\
\text { school } \\
\text { No (\%) }\end{array}$ & $\begin{array}{l}\text { Total } \\
\text { No (\%) }\end{array}$ \\
\hline Pain & $43(68)$ & $71(43)$ & $114(50)$ \\
No pain & $20(32)$ & $96(57)$ & $116(50)$ \\
Total & 63 & 167 & 230 \\
\hline
\end{tabular}

$\chi^{2}=12 \cdot 1, \mathrm{df}=1, \mathrm{p}<0 \cdot 0001$.

Table 5 Prevalence of pain in music and regular schools-girls

\begin{tabular}{llll}
\hline & $\begin{array}{l}\text { Music } \\
\text { school } \\
\text { No }(\%)\end{array}$ & $\begin{array}{l}\text { Regular } \\
\text { school } \\
\text { No }(\%)\end{array}$ & $\begin{array}{l}\text { Total } \\
\text { No }(\%)\end{array}$ \\
\hline Pain & $77(73)$ & $102(56)$ & $179(62)$ \\
No pain & $29(27)$ & $79(44)$ & $108(38)$ \\
Total & 106 & 181 & 287 \\
\hline
\end{tabular}

$\chi^{2}=7.6, \mathrm{df}=1, \mathrm{p}<0.01$.
The large amount of time spent on music seems to $\frac{}{n}$ exact a price more severe (although perhaps less surprising) than does the time spent writing in the regular school. What activities contribute most tothis pain? We shall look at this in more detail next.

INSTRUMENTS PLAYED

We began by assuming that the first instrument $\cong$ nominated by each child was the one to which the ${ }^{\infty}$ most time would be devoted. An initial cross $\vec{\circ}$ tabulation between the reporting of pain and the $\overrightarrow{\vec{A}}$ first instrument named identified the piano, violin, $\stackrel{\omega}{\circ}$ cello, clarinet, and flute as the instruments most associated with the occurrence of pain. There were? others used as first instruments by comparatively 0 few students for which the proportions were high $\vec{N}$ but less convincing because of the smaller numbers. 0 These included the guitar (4/4), harp (4/4), French $\infty$ horn (4/5) and bassoon (3/3). Table 6 records, for을 the piano, violin, cello, clarinet, and flute, thenumbers and proportions of students reporting pain (a) when it was their first instrument and $(b)$ when the instrument was played at all.

The piano was more often played as a second instrument, but the prevalence of pain was high whether it was first instrument or not. The viog was more often first instrument, and the ceno. exclusively first. It was found that pain was almogt always associated with playing of the cello; less certain because of the smaller numbers, but also of concern, was the high prevalence of pain associated with the clarinet and the flute.

Firm conclusions cannot be reached for instru- $\vec{P}$ ments where the numbers are small. We considered 3 it worthwhile, however, to look at the prevalence of pain for different categories of instruments, definedo as follows: keyboard (piano, organ, harpsichord), strings (violin, viola, cello, bass, guitar, harp), brass (trumpet, trombone, French horn, tuba), and wood-윽 wind (clarinet, oboe, flute, bassoon, recorder, saxophone). Table 7 shows the prevalence of paino for those playing each category of instrument. For none of the instrument categories was there a음 significant difference between the likelihood of pain $>$ for those using and not using the instrument. In

Table 6 Prevalence of pain for selected instruments

\begin{tabular}{|c|c|c|c|c|}
\hline Instrument & $\begin{array}{l}\text { As first } \\
\text { No }\end{array}$ & $\begin{array}{c}\text { ment } \\
\%\end{array}$ & $\begin{array}{l}\text { Played at all } \\
\text { No }\end{array}$ & $\%$ \\
\hline Piano & $30 / 44$ & 68 & $100 / 142$ & 70 \\
\hline Violin & $28 / 44$ & 64 & $32 / 48$ & 67 \\
\hline Cello & $17 / 18$ & 94 & $17 / 18$ & 94 \\
\hline Clarinet & $6 / 7$ & 86 & $8 / 9$ & 89 \\
\hline Flute & $8 / 9$ & 89 & $9 / 11$ & 82 \\
\hline
\end{tabular}


Table 7 Prevalence of pain for four categories of instrument

\begin{tabular}{llrlr}
\hline $\begin{array}{l}\text { Instrument } \\
\text { category* }\end{array}$ & $\begin{array}{l}\text { Number who } \\
\text { play }\end{array}$ & $\begin{array}{l}\text { No (\%) } \\
\text { reporting } \\
\text { pain }\end{array}$ & $\begin{array}{l}\text { Number not } \\
\text { playing }\end{array}$ & $\begin{array}{l}\text { No (\%) } \\
\text { reporting } \\
\text { pain }\end{array}$ \\
\hline Keyboard & 143 & $101(71)$ & 26 & $19(73)$ \\
Strings & 90 & $68(76)$ & 79 & $52(66)$ \\
Brass & 21 & $12(57)$ & 148 & $108(73)$ \\
Woodwind & 32 & $24(75)$ & 137 & $96(70)$ \\
\hline
\end{tabular}

${ }^{*}$ Keyboard=piano, organ, harpsichord; strings=violin, viola, cello, bass, guitar, harp; brass =trumpet, trombone, French horn, tube; woodwind=clarinet, oboe, flute, bassoon, recorder, saxophone.

interpreting these results, it is important to note that those not using any specified instrument type were using others in its place. Users of all instrument types, except brass, recorded substantially higher rates of reported pain than the children in the regular school.

To conclude, pain was experienced fairly uniformly across the various instrument types, and for all types was substantially higher than for children not engaged in playing musical instruments. The instrument most strongly associated with pain was the cello (17/18), and the group of instruments least associated with pain was brass.

\section{PRACTICE TIME}

In view of the long hours of practice reported one might have reasonably expected to find an association between practice time and the prevalence of pain. Two indicators of practice time were available: the stated average hours a day and the stated maximum hours a day. Each was split as near as possible to the median and cross tabulated with the incidence of reported pain. Table 8 presents the results obtained. In each case the longer practice time was associated with greater prevalence of pain, but neither relation achieved statistical significance.

Table 8 Prevalence of pain and practice hours a day

\begin{tabular}{|c|c|c|c|c|}
\hline & \multicolumn{2}{|c|}{ Average daily practice* } & \multicolumn{2}{|c|}{ Maximum daily practice ${ }^{\dagger}$} \\
\hline & $\begin{array}{l}3 \text { Hours } \\
\text { and less } \\
\text { No }(\%)\end{array}$ & $\begin{array}{l}\text { More than } \\
3 \text { hours } \\
\text { No }(\%)\end{array}$ & $\begin{array}{l}\text { Less than } \\
5 \text { hours } \\
\text { No }(\%)\end{array}$ & $\begin{array}{l}5 \text { Hours } \\
\text { and more } \\
\text { No }(\%)\end{array}$ \\
\hline Pain & $73(70)$ & 47 (73) & $50(67)$ & $70(74)$ \\
\hline No pain & $32(30)$ & $17(27)$ & $25(33)$ & 24 (26) \\
\hline Total & 105 & 64 & 75 & 94 \\
\hline
\end{tabular}

${ }^{*} \chi^{2}=0 \cdot 3, \mathrm{df}=1$, NS

$+\chi^{2}=1 \cdot 2, \mathrm{df}=1$, NS.
The relation was stronger for maximum practice hours than for average practice hours, suggesting that periods of intense practice may be a stronger determinant of pain than the average level of practice. This warrants further investigation, given the tentative statistical evidence.

\section{GRA D E LEVEL}

Although the prevalence of pain was constant across ages, it was considered that pain might be related to the grade level reached in music, but the evidence for this was unconvincing. The lowest prevalence of pain was among those with the lowest grade levels, and the highest prevalence among those at grade levels 9 and 10. Although the trend was in the expected direction, it fell short of statistical significance.

\section{Discussion}

The prevalence of writing related pain was twice as high in the control group in this study as that reported previously in the Australian study. ${ }^{5}$ In this study, however, writing related pain was significantly more common among the female than among the male population. Evidence of a gender difference for music related pain $^{57}$ also existed among the music school pupils, but did not reach statistical significance. The data suggest that the critical factor may be the intensity of practice rather than just the actual hours spent practising. This is supported by the observation that music related overuse may start with one particular work which is particularly demanding, while initially other works do not cause pain. Observations on the events preceding the first symptoms in many of these patients suggest the importance of the increased intensity of practice.

Traditionally, musicians feel that they have to practise to the point of pain to achieve maximum benefit ('No pain, no gain'). This dictum is particularly dangerous in young people as the point will come when the pain no longer disappears with rest and the musical career is threatened.

The music school students, who are carefully monitored medically, reported no morning stiffness or joint swellings. The pain reported would have to be the common musculoligamentous pain of overuse syndrome, very common in musicians. This is a condition of pain and loss of function in muscle groups and ligaments due to excessive or unaccustomed use. Although the intensity multiplied by the time of practice is probably the most important factor, the musician's technique, if tense and involving excessive and wasteful muscular effort, may also contribute. Apparently some individuals are genetically more vulnerable to overuse than others. ${ }^{38}$ 


\section{Conclusion}

Last century both the painful and the painless forms of overuse were most commonly brought about by writing. ${ }^{9}$ The data here, showing $26 \%$ of the regular school population affected by writing related pain, are cause for concern and worthy of further investigation, as is the apparently greater vulnerability of girls. Techniques of writing, including the avoidance of unnecessarily excessive muscle power, should probably be taught in primary schools.

The music related pain reported by the gifted music students is cause for particular concern, and, in the absence of other identifiable pain causing processes, is almost certain to be overuse syndrome. Students with persisting pain and pain at rest indicate a worse grade of the disorder in which the musculoskeletal structures have not been able to recover from the high demand. Theoretically, all overuse should be preventable by the control of use and by segmentalised controlled practice; the proper use of muscle power for posture and support of the instruments needs to be addressed if these high figures are to be reduced. The repertoire should be chosen for the student's present ability. Above all, students should be taught not to practise through pain as has been the custom in the past.
We are very grateful to Michael Brewer, director of music at Chetham's school of music in Manchester and the headmaster fores? permitting their students to take part in this survey.

\section{References}

1 Newmark J, Hochberg F H. 'Doctor, it hurts when I play $\vec{D}$ painful disorders among instrumental musicians. Medical Prob. lems of Performing Artists 1987: 2: 93-9.

2 Manchester R A. The incidence of hand problems in musicstudents. Medical Problems of Performing Artists 1988: 3: 15-19.

3 Fry $\mathrm{H} \mathrm{J} \mathrm{H}$. Overuse syndrome in musicians: prevention an management. Lancet 1986; ii: 728-31.

4 Dennett X, Fry H J H. Overuse syndrome: a muscle biops study. Lancet 1988; i: $905-8$.

5 Fry H J H, Ross P, Rutherford M. Music-related overuse a secondary school. Medical Problems of Performing Artists 1988 N 3: $133-4$.

6 Lockwood A H. Medical problems in secondary school-age 90 musicians. Medical Problems of Performing Artists 1988; 4음 129-32.

7 Fry $\mathrm{H} \mathrm{J} \mathrm{H}$. Patterns of overuse seen in 658 affected instrumentamusicians. International Journal of Music Education 1988: 3-16Ф

8 Lockwood A H. Medical problems of musicians. $N$ Engl J Med 1989: 320: 221-7.

9 Poore G V. An analysis of 93 cases of writer's cramp and impaired writing power. making with 75 cases previofll $-\overrightarrow{0}$ reported a total of 168 cases. Medicochirurgical Transact 1887; 52: 301-33 